\title{
Rapeseed (Brassica napus L. var. oleifera) response to nitrogen fertilizer following different previous crops
}

\author{
Seyyed A. Siadat, Mohammad R. Moradi-Telavat, Ghodratollah Fathi, Maryam Mazarei, \\ Khalil Alamisaeid, Seyyed H. Mousavi \\ Ramin Agriculture and Natural Resources University, Mollasani, Ahwaz, Iran
}

\begin{abstract}
This study was conducted in the crop years 2007-1010 and aimed to evaluate the effects of previous crops and use of nitrogen $(\mathrm{N})$ fertilizer on rapeseed productivity in Ahwaz, Iran. The previous crops were: i) barley + clover; ii) rapeseed; iii) corn; iv) mung-bean; v) rice; and vi) wheat. $\mathrm{N}$ fertilizer was applied to rapeseed at rates of $0,100,160$ and $220 \mathrm{~kg} \mathrm{ha}^{-1}$. The effects of management on yield and product oil content and oil yield were assessed. The effect of the previous crop and the use made of $\mathrm{N}$ fertilizer both affected rapeseed productivity. The results of two repeated experiments showed that the lowest seed and oil yields were obtained when unfertilized rapeseed followed rice. The highest seed and oil yields were obtained when rapeseed production followed mung-bean as the previous crop (range 160-220 kg ha-1 N rate). Among yield components, previous crops and $\mathrm{N}$ rates significantly influenced the silique number per unit area, and this showed a similar variation to that of seed yield. Data averaged across 2-year periods indicated that the highest oil content occurred in unfertilized rapeseed plots when the effects of the previous crop were not significant. Nevertheless, rapeseed following mung-bean receiving 150-220 $\mathrm{kg} \mathrm{ha}^{-1} \mathrm{~N}$ rates produced the highest yield in the two years in which the experiment was repeated. Rapeseed following mung-bean and receiving $160 \mathrm{~kg} \mathrm{~N} . \mathrm{ha}^{-1}$ had also the highest nutrient use efficiency parameters.
\end{abstract}

Correspondence: Dr. Mohammed R. Moradi-Telavat, Ramin Agriculture and Natural Resources University, Mollasani, Ahwaz, Iran 63417-73637.

Tel. +98.6123224338 - Fax: +98.6123224338.

E-mail:moraditelavat@yahoo.com

Key words: rapeseed, Brassica napus L. var. oleifera, mung-bean, N fertilizer, oil content, rotation, yield.

Acknowledgements: the authors would like to thank Iran National Science Funding (INSF) for supporting this work.

Received for publication: 13 May 2011.

Accepted for publication: 22 August 2011.

(C) Copyright S.A. Siadat et al., 2011

Licensee PAGEPress, Italy

Italian Journal of Agronomy 2011; 6:e31

doi:10.4081/ija.2011.e31

This work is licensed under a Creative Commons Attribution NonCommercial 3.0 License (CC BY-NC 3.0).

\section{Introduction}

The efficient use of fertilizers is one of the most important factors in maximizing crop yield and sustainability. Crop nitrogen $(\mathrm{N})$ use efficiency is related to climatic conditions, soil properties and the interaction between nutrient elements. Compared to cereals, rapeseed requires a higher amount of nutrients, and available nitrogen frequently limits seed yield. The $\mathrm{N}$ requirement of rapeseed is two times that of cereals (Grant and Bailey, 1993; Ahmad et al., 2007). Colnenne et al. (1998) proposed that to produce $0.1 \mathrm{t}$ of seeds, the whole crop accumulates approximately $6 \mathrm{~kg}$ of $\mathrm{N}$. Moradi-Telavat et al. (2008) reported that $\mathrm{N}$ increased rapeseed grain and oil yield through increased silique number and grain weight. But a significant negative effect of $\mathrm{N}$ on grain oil content has been observed (Malhi and Gill, 2004; Moradi-Teavat et al., 2008). Others (Rathke et al., 2005; Colnenne et al., 1998) have underlined the significance of higher soil nutrient and particularly $\mathrm{N}$ availability in determining the yield quantity and quality of rapeseed.

While a substantial amount of $\mathrm{N}$ is provided by conversion of previous crop residues and organic soil matter into soluble soil nitto, additional mineral $\mathrm{N}$ is a prerequisite for high yields. Several investigations confirmed that rapeseed yields following cereal crops were substantially lower than when rapeseed was grown after pea (Pisum sativum L.) (Christen and Sieling, 1995; Sieling et al., 1997). Christen (2001) reported that winter rapeseed yielded as high as $3.98 \mathrm{t} \mathrm{ha}^{-1}$ after pea compared to $3.70 \mathrm{t} \mathrm{ha}^{-1}$ after winter barley and $3.50 \mathrm{t} \mathrm{ha}^{-1}$ after winter wheat. Furthermore, $\mathrm{N}$ input from organic fertilizer and biological $\mathrm{N}_{2}$ fixation might be a substantial source of $\mathrm{N}$ depending on the farming system. Nitrogen sources influencing yield in rapeseed include mineral $\mathrm{N}$ in inorganic fertilizers, $\mathrm{N}$ mineralized from organic fertilizers, and $\mathrm{N}$ mineralized from residue of the previous crop (Rathke et al., 2005).

Crop rotation management in the Ahwaz region in southwest Iran has been influenced by various factors, including government policy at the Ministry of Agriculture, climatic conditions in different soils, etc. Farmers have, therefore, adopted different approaches to crop rotation according to the different conditions. This has had a negative effect, especially in terms of sustainable income and the environment. The objective of this research was to determine which were the best previous crops for rapeseed cultivation to follow and the optimal $\mathrm{N}$ rate for the region.

\section{Materials and Methods}

The study was carried out at the Ramin (Mollasani) Agriculture and Natural Resources University of Ahwaz, Iran, in the crop years 20072008, 2008-2009 and 2009-2010. Data concerning soil properties and 
meteorological conditions are shown in Tables 1 and 2, respectively. The main experiment was carried out on a split plot arranged in a randomized complete block design with three replications. The crops which were to precede rapeseed cultivation (previous crops) were applied to the main plots and four $\mathrm{N}$ fertilizer levels $(0,100,160$ and $220 \mathrm{~kg} \mathrm{~N} . \mathrm{ha}^{-1}$ ) were applied to the subplots; subplots were $1.6 \mathrm{~m}$ wide ( 8 rapeseed lines with a distance of $0.2 \mathrm{~cm}$ between them) and $4 \mathrm{~m}$ long. The previous crops, planted in autumn and summer of the 20072008 crop year, were: 1) rapeseed (Brassica napus L.); 2) wheat; 3) corn; 4) rice; 5) barley + berseem clover (Trifolium alexandrinum L.); and 6) mung-bean. Different lengths of time elapsed between the harvesting of previous crops and planting of the target crop (rapeseed) because of the different growing seasons in the region (Table 3 ). The target crop (rapeseed) was then planted in the autumn of 2008 in all plots. The experiment was repeated in the 2008-2009 crop years (previous crops) and 2009-2010 (target crop: rapeseed). The experimental area was disc harrowed and Treflan (Trifloralin) was applied prior to seeding to control grasses at a rate of $1 \mathrm{~L} \mathrm{ha}^{-1}$.

Nitrogen fertilizer, applied as urea [ $\left.\left(\mathrm{NH}_{2}\right)_{2} \mathrm{CO}\right]-\mathrm{N}$, was banded to the sides of the seed rows. Banding was carried out in three phases: onethird of the quantity two weeks after emergence, one-third on stem elongation, and one-third at the budding stage. Phosphorus, applied as triple-superphosphate, was applied before seeding and was incorporated into the soil with a conventional disk. Conventional tillage was performed to kill weeds before seeding. In addition, hand weeding was carried out during the rapeseed growing season if needed. Nitrogen use efficiency (NUE) was calculated according to the formula:

$$
\text { N Agronomic efficiency } \frac{\text { Yield }_{\mathrm{Nx}}-\text { Yield }_{\mathrm{N} 0}}{{\text { Apllied } \mathrm{N}_{\mathrm{Nx}}}}
$$

Rapeseed plants were harvested 2-3 cm above ground level at maturity from a $1-\mathrm{m}^{2}$ area of each subplot. After being taken to the laboratory, the samples were analyzed for grain yield and its components. The rapeseed seed yield was adjusted to $9 \%$ moisture content. Oil content was calculated using the Nuclear Magnetic Resonance (NMR) analysis method (Jenkins 1996). Data were Mix analyzed by GLM procedure using SAS programs (SAS Release 9.2, SAS Institute Inc., Cary, NC, USA). Differences among treatment means were determined using Duncan's Multiple Range Test (DMRT) at 0.05 level of probability.

\section{Results}

\section{Yield and its components}

Results of this study showed that previous crop and $\mathrm{N}$ fertilizer both significantly affected seed yields (Table 4). But the interaction between previous crop and $\mathrm{N}$ levels was not significant. As expected, those plots which received no $\mathrm{N}$ fertilizer had lower yields regardless of which crop had preceded rapeseed cultivation. In addition, the effect of $\mathrm{N}$ treat- ment on seed yield was consistent for all previous crops (Table 5). There was a significant difference in the effect of $\mathrm{N}$ on rapeseed seed yield between the two repeated experiments of the research (20082009 and 2009-2010). The highest yield was obtained at the range of $160-220 \mathrm{~kg} \mathrm{ha}^{-1} \mathrm{~N}$ rates in the first year experiment whereas $\mathrm{N}$ application over $160 \mathrm{~kg}$ caused a significant decrease in rapeseed seed yield in the second year (Table 5).

The effect of the previous crop on the rapeseed seed yield was the same in the two years of research (Table 5). Rapeseed yield was greater following mung-bean than other previous crops. The lowest yield in both years of the experiment was obtained when rapeseed was planted after paddy rice. In the Ahwaz region, the time between harvesting the rice and seeding the rapeseed is limited. This means that optimal tillage options cannot be applied and an appropriate small rapeseed seed bed cannot be prepared, resulting in weak seedlings and subsequent lower yields in comparison to other previous crops.

The effect of $\mathrm{N}$ and previous crop on the dry matter of rapeseed was also significant (Table 4). As shown in Table 6, rapeseed produced the highest dry matter at an $\mathrm{N}$ rate of $160 \mathrm{~kg} \mathrm{~N} \cdot \mathrm{ha}^{-1}$ and following mungbean. Both previous crop and $\mathrm{N}$ treatment significantly affected rapeseed grain weight (Table 4). The highest value of grain weight was obtained following mung-bean and there was no significant difference in grain weight among other previous crops (Table 5). The use of $\mathrm{N}$ fertilizer resulted in a significant increase in rapeseed grain weight. Grain weight increased significantly at an $\mathrm{N}$ rate of $160 \mathrm{~kg} \mathrm{ha}^{-1} \mathrm{~N}$ and this increase was consistent up to an $\mathrm{N}$ rate of $220 \mathrm{~kg} \mathrm{ha}^{-1}$ (Table 5).

\section{Oil content and yield}

The effects of $\mathrm{N}$ management and previous crop on oil content are shown in Table 4. The comparison between previous crops showed that the lowest and highest grain oil content was obtained in rapeseed following corn and mung-bean, respectively (Table 5). Nitrogen fertilizer significantly decreased oil content (Table 5). Therefore, the highest oil content was obtained when no fertilizer was used and the lowest oil content was observed at an $\mathrm{N}$ rate of $220 \mathrm{~kg} \mathrm{ha}^{-1}$. Generally, the oil yield in both years of the experiment conformed closely to the seed yield (Table 5 and 6). Also the highest and the lowest values of rapeseed oil yield were observed following mung-bean and rice, respectively (Table $5)$. In contrast to grain oil content, rapeseed produced the highest oil yield at $\mathrm{N}$ rates of $160-220 \mathrm{~kg} \mathrm{ha}^{-1}$ (Table 5). Similar to results seen with seed yield, oil yield decreased significantly when $\mathrm{N}$ rates were increased from 160 up to $220 \mathrm{~kg} \mathrm{ha}^{-1}$.

Table 1. Physiochemical properties of soil on the research farm.

\begin{tabular}{|c|c|c|c|c|c|c|c|}
\hline $\begin{array}{l}\text { Soil depth } \\
(\mathrm{cm})\end{array}$ & $\begin{array}{c}\mathbf{N} \\
(\%)\end{array}$ & P & $\begin{array}{c}\mathrm{K} \\
\mathrm{mg} \cdot \mathrm{kg}^{-1}\end{array}$ & $\mathrm{pH}$ & EC & $\begin{array}{c}\text { Organic } \\
(\mathrm{ds.m-1}) \\
(\%)\end{array}$ & $\begin{array}{l}\text { Texture } \\
\text { matter }\end{array}$ \\
\hline $0-30$ & 0.06 & 7 & 224 & 7.7 & 3.4 & 0.5 & Clay-loamy \\
\hline $30-60$ & 0.03 & 3 & 128 & 7.8 & 3 & 0.42 & Loamy-clay \\
\hline
\end{tabular}

Table 2. Meteorological and climatic data during rapeseed growing season.

\begin{tabular}{|c|c|c|c|c|}
\hline & \multicolumn{2}{|c|}{$2008-2009$} & \multicolumn{2}{|c|}{$2009-2010$} \\
\hline & Mean temperature $\left({ }^{\circ} \mathrm{C}\right)$ & Precipitation (mm) & Mean temperature $\left({ }^{\circ} \mathrm{C}\right)$ & Precipitation (mm) \\
\hline December & 15.9 & 15.4 & 15.7 & 113.3 \\
\hline January & 12.3 & 0 & 15.7 & 21.5 \\
\hline February & 15.8 & 30.3 & 16.2 & 17.8 \\
\hline March & 19.7 & 3.3 & 21.7 & 3.2 \\
\hline April & 26.7 & 1.2 & 22 & 18.7 \\
\hline
\end{tabular}


Both previous crop and $\mathrm{N}$ rate significantly affected NUE. Thus, rapeseed following mung-bean and rice showed the highest and the lowest NUE, respectively (Table 5). In addition, an increase in $\mathrm{N}$ up to $220 \mathrm{~kg}$ $\mathrm{ha}^{-1}$ resulted in a significant decrease in NUE. Rapeseed planted following mung-bean and receiving 100 and $160 \mathrm{~kg} \mathrm{~N} \mathrm{ha}^{-1}$ had the highest NUE (Table 6).

\section{Discussion}

Previous crop and the crop $\mathrm{N}$ fertilization applied affect both yield and quality of the rapeseed and have an impact on its importance as an economically viable biomass source. Only a few publications have dealt with the effects of previous crops on subsequent rapeseed cultivation (e.g. Christen, 2001; Sieling et al., 1997; and Rathke et al., 2005). Nevertheless, the benefits of rapeseed on the subsequent crop have mostly been assessed in a variety of publications (Prew et al., 1986; Christen et al., 1992; Christen, 2001). Rathke et al. (2005) and Christen and Sieling (1995) reported that yield from rapeseed cultivation following cereal crops was substantially lower than when cultivated after pea, thus supporting the results of this study. In the present study, rapeseed following mung-bean resulted in a greater yield than after other previ- ous crops. The benefit of the legume is related to both $\mathrm{N}$ and the effects of complex rotation procedures. However, in our present study conditions, and due to the period of the growing season of the region, the length of time which elapsed between harvesting the previous crop and rapeseed seeding differed (Table 3); for example, rapeseed is seeded approximately six months later than barley plus clover. Therefore, the effect of these previous crops is also influenced by the time factor as part of the effects of complex rotation procedures.

As a result, $\mathrm{N}$ fertilizer affected seed yield independently of the pre-

Table 3. Sowing and harvest time of previous crops in both years 2007-2008 and 2008-2009.

\begin{tabular}{|c|c|c|}
\hline Previous crop & Sowing date & Harvest date \\
\hline Barley + clover & $10-20$ Nov & 10-20 May \\
\hline $\begin{array}{l}\text { Rapeseed (as both previous } \\
\text { and target crop) }\end{array}$ & 20-30 Nov & 10-20 May \\
\hline Corn & 20-30 Jul & 20-30 Oct \\
\hline Mung-bean & $1-10 \mathrm{Jul}$ & $1-10$ Oct \\
\hline Rice & 20-30 Jun & 20-30 Oct \\
\hline Wheat & 20-30 Nov & 20-30 May \\
\hline
\end{tabular}

Table 4. Mixed analysis of variance of rapeseed yield and its components affected by treatments.

\begin{tabular}{|c|c|c|c|c|c|c|c|c|}
\hline S.0.V & df & $\begin{array}{l}\text { Mean squares } \\
\text { Grain yield }\end{array}$ & Dry matter & Oil yield & $\begin{array}{c}\text { Silique } \\
\text { number. } \text { m }^{-2}\end{array}$ & $\begin{array}{l}\text { Grain/ } \\
\text { silique }\end{array}$ & $\begin{array}{l}\text { Grain } \\
\text { weight }\end{array}$ & $\begin{array}{l}\text { Oil } \\
\text { content }\end{array}$ \\
\hline Year $(\mathrm{Y})$ & 1 & $11093377^{* *}$ & 61528229 & $2866815^{* *}$ & 1472820 & $585^{* *}$ & $72^{* *}$ & $86.0^{* *}$ \\
\hline Year*block & 4 & 89275 & 2338488 & 20954 & 3513608 & 5.1 & 0.0 & 0.5 \\
\hline Previous crop (P) & 5 & $3210440 * *$ & $37977738 * *$ & $667237^{* *}$ & $15233002^{* *}$ & 15.6 & $0.2^{* *}$ & $6.7^{* *}$ \\
\hline $\mathrm{P} * \mathrm{Y}$ & 5 & 612822 & $12925319 * *$ & 123979 & $12474170 * *$ & 12 & 0.0 & 2.9 \\
\hline $\mathrm{Y} * \mathrm{P} * \mathrm{R}$ & 20 & 504742 & 1752604 & 101564 & 2353187 & 7.6 & 0.0 & 0.4 \\
\hline Nitrogen $(\mathrm{N})$ & 3 & $21858208^{* *}$ & $202753784^{* *}$ & $3965432^{* *}$ & $62092738^{* *}$ & $65.6^{* *}$ & $0.4^{* *}$ & $34.7^{* *}$ \\
\hline $\mathrm{P} * \mathrm{~N}$ & 15 & 561960 & 5080431 & 100958 & 2085113 & 7.1 & 0.0 & 0.8 \\
\hline $\mathrm{N} * \mathrm{Y}$ & 3 & $1180757^{*}$ & 8110341 & $246271^{*}$ & $9160413^{* *}$ & $13.8^{*}$ & 0.02 & 0.8 \\
\hline $\mathrm{P} * \mathrm{~N} * \mathrm{Y}$ & 15 & 579889 & 4469625 & 110385 & 1559158 & 7.3 & 0.04 & 1.5 \\
\hline Res. error & 72 & 359676 & 2720808 & 71440 & 2002628 & 4.5 & 0.04 & 0.5 \\
\hline C.V & 25.5 & 20.3 & 25.8 & 24.2 & 11.0 & 6.3 & 1.7 & \\
\hline
\end{tabular}

*,**significant in $5 \%$ and $1 \%$ probability, respectively.

Table 5. Means comparison for yield and yield components under experimental factors with Duncan's Multiple Range Test.

\begin{tabular}{|c|c|c|c|c|c|c|c|c|}
\hline & $\begin{array}{l}\text { Grain yield } \\
\left(\mathrm{kg}_{\mathrm{h}} \mathrm{ha}^{-1}\right)\end{array}$ & $\begin{array}{l}\text { Dry matter } \\
\left(\mathrm{kg}_{\mathrm{ha}} \mathrm{a}^{-1}\right)\end{array}$ & $\begin{array}{l}\text { Oil yield } \\
\left(\mathrm{kg} \mathrm{ha}^{-1}\right)\end{array}$ & Silique $\mathrm{m}^{-2}$ & $\begin{array}{l}\text { Grain/ } \\
\text { silique }\end{array}$ & $\begin{array}{c}\text { Grain } \\
\text { weight (g) }\end{array}$ & $\begin{array}{c}\text { Oil } \\
\text { Content (\%) }\end{array}$ & NUE \\
\hline \multicolumn{9}{|l|}{ Year } \\
\hline 2008-2009 & $2068^{b}$ & $7509 \mathrm{~b}$ & $891^{b}$ & $5762^{\mathrm{a}}$ & $17.1^{\mathrm{b}}$ & $4.05^{\mathrm{a}}$ & $43.3^{b}$ & $10.7^{\mathrm{a}}$ \\
\hline $2009-2010$ & $2616^{\mathrm{a}}$ & $8720^{a}$ & $1171^{\mathrm{a}}$ & $5904^{\mathrm{a}}$ & $21.2^{\mathrm{a}}$ & $2.62^{\mathrm{b}}$ & $44.9^{\mathrm{a}}$ & $10.5^{\mathrm{a}}$ \\
\hline \multicolumn{9}{|l|}{ Previous crops } \\
\hline Mung-bean & $2942^{\mathrm{a}}$ & $10044^{\mathrm{a}}$ & $1311^{\mathrm{a}}$ & $7319^{a}$ & $18.6^{\mathrm{a}}$ & $3.47^{\mathrm{a}}$ & $44.7^{\mathrm{a}}$ & $14.4^{\mathrm{a}}$ \\
\hline Canola & $2421^{b}$ & $8529^{b}$ & $1059^{b}$ & $5314^{\mathrm{bc}}$ & $18.1^{\mathrm{a}}$ & $3.30^{\mathrm{b}}$ & $43.9 \mathrm{~cd}$ & $11.7^{\mathrm{ab}}$ \\
\hline Barley + clover & $2373^{b}$ & $8415^{b}$ & $1049^{b}$ & $5993^{\mathrm{bc}}$ & $20.2^{\mathrm{a}}$ & $3.29 \mathrm{~b}$ & $44.3^{\mathrm{bc}}$ & $8.7^{c}$ \\
\hline Corn & $2285^{b}$ & $7911^{\mathrm{b}}$ & $1013^{b}$ & $5157^{c}$ & $19.9^{\mathrm{a}}$ & $3.41^{\mathrm{a}}$ & $43.3^{\mathrm{e}}$ & $12.4^{\mathrm{a}}$ \\
\hline Wheat & $2276^{\mathrm{b}}$ & $7755^{\mathrm{b}}$ & $987^{b}$ & $6249^{b}$ & $19.6^{\mathrm{a}}$ & $3.29 \mathrm{~b}$ & $44.6^{\mathrm{ab}}$ & $9.2^{\mathrm{bc}}$ \\
\hline Rice & $1791^{\mathrm{c}}$ & $6116^{c}$ & $788^{c}$ & $5064^{c}$ & $19.2^{\mathrm{a}}$ & $3.25^{\mathrm{b}}$ & $43.7^{\mathrm{de}}$ & $7.3^{\mathrm{c}}$ \\
\hline \multicolumn{9}{|l|}{ Nitrogen $\left(\mathrm{Kg} \cdot \mathrm{ha}^{-1}\right)$} \\
\hline 0 & $1235^{\mathrm{d}}$ & $4726^{c}$ & $561^{d}$ & $4006^{c}$ & $17.4^{\mathrm{b}}$ & $3.21^{\mathrm{b}}$ & $45.1^{\mathrm{a}}$ & - \\
\hline 100 & $2282^{c}$ & $7871^{\mathrm{b}}$ & $1021^{c}$ & $5738^{b}$ & $19.5^{\mathrm{a}}$ & $3.28^{b}$ & $44.5^{b}$ & $13.0^{\mathrm{a}}$ \\
\hline 160 & $3078^{a}$ & $9880^{a}$ & $1359^{a}$ & $7291^{\mathrm{a}}$ & $20.4^{\mathrm{a}}$ & $3.43^{\mathrm{a}}$ & $44.0^{c}$ & $12.0^{\mathrm{a}}$ \\
\hline 220 & $2730^{\mathrm{b}}$ & $9828^{a}$ & $1170^{\mathrm{b}}$ & $6194^{b}$ & $19.4^{\mathrm{a}}$ & $3.42^{\mathrm{a}}$ & $42.8^{\mathrm{d}}$ & $7.4^{b}$ \\
\hline
\end{tabular}

a-esimilar letters in each column show no significant difference between treatments at $5 \%$ of probability. 
Table 6. Mean comparison of grain yield, oil yield and NUE, with Duncan's Multiple Range Test.

\begin{tabular}{|c|c|c|c|c|}
\hline $\begin{array}{l}\text { Treatment } \\
\text { Previous crop }\end{array}$ & Nitrogen (kg.ha $\left.{ }^{-1}\right)$ & Grain yield $\left(\mathrm{kg} \mathrm{ha}^{-1}\right)$ & Oil yield $\left(\mathrm{kg} \mathrm{ha}^{-1}\right)$ & NUE (kg.kag-1) \\
\hline Mung-bean & 0 & $1438^{i j k}$ & $661^{\text {ghi }}$ & - \\
\hline Canola & 0 & $1117^{\mathrm{jk}}$ & $502^{\mathrm{hi}}$ & - \\
\hline Barley + clover & 0 & $1644^{\text {hijk }}$ & $749^{\text {fghi }}$ & - \\
\hline Corn & 0 & $904^{\mathrm{k}}$ & $410^{i}$ & - \\
\hline Wheat & 0 & $1247^{\mathrm{jk}}$ & $574^{\mathrm{hi}}$ & - \\
\hline Rice & 0 & $1110^{\mathrm{jk}}$ & $491^{\mathrm{hi}}$ & - \\
\hline Mung-bean & 100 & $2662^{\text {bcdef }}$ & $1213^{\text {bcde }}$ & $20.40^{\mathrm{a}}$ \\
\hline Canola & 100 & $2373^{\text {cdefgh }}$ & $1048^{\text {cdef }}$ & $13.30^{\mathrm{bcd}}$ \\
\hline Barley + clover & 100 & $2158^{\text {efghi }}$ & $969^{\text {defg }}$ & $11.50^{\text {cde }}$ \\
\hline Corn & 100 & $2251^{\text {defghi }}$ & $990^{\text {cdefg }}$ & $15.90^{\mathrm{abc}}$ \\
\hline Wheat & 100 & $2319^{\text {cdefgh }}$ & $1058^{\text {cdef }}$ & $11.70^{\text {bcde }}$ \\
\hline Rice & 100 & $1926^{\text {fghij }}$ & $842^{\text {efgh }}$ & $8.20^{\mathrm{def}}$ \\
\hline Mung-bean & 160 & $4153^{\mathrm{a}}$ & $1854^{\mathrm{a}}$ & $17.00^{\mathrm{ab}}$ \\
\hline Canola & 160 & $3132^{\mathrm{bc}}$ & $1371^{\mathrm{bc}}$ & $13.30^{\mathrm{bcd}}$ \\
\hline Barley + clover & 160 & $3051^{\text {bcd }}$ & $1351^{\mathrm{bcd}}$ & $10.50^{\mathrm{def}}$ \\
\hline Corn & 160 & $3005^{\text {bcde }}$ & $1296^{\mathrm{bcd}}$ & $13.10^{\mathrm{bcd}}$ \\
\hline Wheat & 160 & $2764^{\text {bcdef }}$ & $1227^{\text {bcde }}$ & $9.50^{\mathrm{def}}$ \\
\hline Rice & 160 & $2368^{\text {cdefgh }}$ & $1053^{\text {cdef }}$ & $7.20^{\mathrm{ef}}$ \\
\hline Mung-bean & 220 & $3514^{a b}$ & $1515^{b}$ & $7.80^{\mathrm{def}}$ \\
\hline Canola & 220 & $2843^{\text {bcde }}$ & $1221^{\text {bcde }}$ & $8.40^{\mathrm{def}}$ \\
\hline Barley + clover & 220 & $2515^{\text {cdefg }}$ & 1078cdef & $5.20^{\mathrm{f}}$ \\
\hline Corn & 220 & $2976^{\text {bcde }}$ & $1252^{\mathrm{bcd}}$ & $9.40^{\mathrm{def}}$ \\
\hline Wheat & 220 & $2776^{\text {bcdef }}$ & $1191^{\text {bcde }}$ & $6.90^{\mathrm{ef}}$ \\
\hline Rice & 220 & $1758^{\text {ghij }}$ & $765^{\text {fghi }}$ & $6.40^{\mathrm{ef}}$ \\
\hline
\end{tabular}

a-ksimilar letters in each column show no significant difference between treatments at $5 \%$ of probability.

vious crop. The positive impact of $\mathrm{N}$ on the seed yield of rapeseed has been repeatedly reported (Jackson, 2000; Hao et al., 2004; MoradiTelavat et al., 2008). Nevertheless, Jackson (2000) noted that optimum seed yield of rapeseed is obtained in the range from 180 to $220 \mathrm{~kg} \mathrm{~N}$ $\mathrm{ha}^{-1}$, depending on site conditions.

An increase in $\mathrm{N}$ resulted in an increase in silique number per unit area; this has been repeatedly reported by others (Moradi-telavat et al., 2008; Fathi et al., 2002). These authors reported that, in a comparative analysis with other yield components such as grain per silique, the most important yield component was rapeseed grain weight. In addition, the positive effect of previous crop on rapeseed seed yield was observed through the increased silique number following mung-bean.

Our results here indicate that seed yield of rapeseed tended to increase as $\mathrm{N}$ rate increased, while oil content of the seed decreased. This inverse relationship might be due to a reduced availability of carbohydrates for oil synthesis when the N supply is high (Rathke et al., 2005). The negative influence of $\mathrm{N}$ fertilization on the oil content of the seeds in our study is consistent with other reports (Mason and Brennan, 1998; Jackson, 2000; Fathi et al., 2002; Moradi-Telavat et al., 2008). However, rapeseed oil yield increased with an increase in $\mathrm{N}$ rates because of the close relationship between rapeseed seed yield and oil yield. Therefore, the highest oil yield was obtained by application of an $\mathrm{N}$ rate of $160 \mathrm{~kg} \mathrm{ha}^{-1}$. Similarly, an increase in rapeseed seed yield following mung-bean resulted in an increase in oil yield compared with following other previous crops in this study.

Calculation of the NUE for rapeseed indicated that the highest NUE was achieved by application of 100 to $160 \mathrm{~kg} \mathrm{~N} \mathrm{ha}^{-1}$ following mungbean. On the basis of the law of diminishing return, the increase in each application of $\mathrm{N}$ fertilizers caused the efficiency of that input to decrease. However, in the present study, the effects of previous crops meant this law did not apply. For instance, the NUE of rapeseed following mung-bean showed no significant decrease in the range of 100 to $160 \mathrm{~kg} \mathrm{~N} \mathrm{ha}^{-1}$.

\section{Conclusions}

In general, the productivity of rapeseed responds dramatically to different $\mathrm{N}$ rates. Under the given conditions, the positive effects of the previous legume (mung-bean) and $\mathrm{N}$ fertilizer were obtained separately. High $\mathrm{N}$ rates caused a decline in the oil content but had positive effects on seed and oil yields of rapeseed. The optimum $\mathrm{N}$ supply depends on whether the objective is to produce high seed yield or high oil content. Oil yield is usually the main management goal, since rapeseed oil is produced as edible oil as well as a renewable energy source. To optimize overall yield as well as oil yield in crop rotation, rapeseed should follow a legume crop like mung-bean and receive a high dose of $\mathrm{N}$. Although the highest oil content was obtained when unfertilized rapeseed was grown regardless of previous crop, the highest oil yield was achieved with $160 \mathrm{~kg} \mathrm{ha}^{-1} \mathrm{~N}$ rate and mung-bean as the previous crop. Future research should include a detailed analysis of fatty acids to determine to what extent a specific composition is affected by $\mathrm{N}$ and crop rotation in this region. Another issue for future research would be to calculate substance and energy fluxes to provide a complete assessment of the environmental effects of $\mathrm{N}$ supply on rapeseed in the Ahwaz region of Iran. 


\section{References}

Ahmad G., Jan A., Arif M., Jan M.T., Khattak R.A., 2007. Influence of nitrogen and sulfur fertilization on quality of canola (Brassica Napus L.) under rainfed conditions. J. Zhejiang Univ. Sci. 8:731737.

Christen 0., 2001. Ertrag, ertragsstruktur und ertragsstabilita"t von Weizen, Gerste und Raps in unterschiedlichen Fruchtfolgen. German. J. Agron. 5:33-39.

Christen 0., Sieling K., 1995. Effect of different preceding crops and crop rotations on yield of winter oilseed rape (Brassica napus L). J. Agron. Crop Sci. 174:265-271.

Colnenne C., Meynard J.M., Reau R., Justes E., Merrien A., 1998. Determination of a critical nitrogen dilution curve for winter oilseed rape. Ann. Bot. 81:311-317.

Fathi G., Banisaeidi A., Siadat S.A., Ebrahimpour F., 2002. The effect of different nitrogen levels and plant density on canola yield in climate conditions of Khouzestan province. Iran Sci. J. Agric. 25: 43-57.

Grant C.A., Bailey L.D., 1993. Fertility management in canola production. Can J. Plant Sci. 73:651-670.

Hao X., Chang C., Travis G.J., 2004. Short communication: effect of long-term cattle manure application on relations between nitrogen and oil content in canola seed. J. Plant Nutr. Soil Sci. 167:214215 .
Jackson G., 2000. Effect of nitrogen and sulphur on canola yield and nutrient uptake. Agron. J. 92:644-649.

Jenkins P.D., Leitch M.H., 1996. Effects of sowing date on the growth and yield of winter oil-seed rape (Brassica napus). J. Agric. Sci. Camb. 107:405-421.

Malhi S.S., Gill K.S., 2004. Placement, rate and source of N, Seedrow opener and seedling depth effects on canola production. Can. J. Plant Sci. 84:719-729.

Mason M.G., Brennan R.F., 1998. Comparison of growth response and nitrogen uptake by canola and wheat following application of nitrogen fertilizer. J Plant Nutr. 21:1483-1499.

Moradi-Telavat M.R., Siadat S.A., Nadian H., Fathi G., 2008. Effect of nitrogen and boron on canola yield and yield components in Ahwaz, Iran. Int. J. Agric. Res. 3:415-422.

Prew R.D., Bean J., Carter N., Church B.M., Dewar A.M., Lacey J., Penny A., Plumb R.T., Todd A.D., 1986. Some factors affecting the growth and yield of winter wheat grown as third cereal with much or negligible take-all. J. Agric. Sci. 107:639-671.

Rathke G.W., Christen 0., Diepenbrock W., 2005. Effects of nitrogen source and rate on productivity and quality of winter oilseed rape (Brassica napus L.) grown in different crop rotations. Field Crops Res. 94:103-113.

Sieling K., Gunther-Borstel 0., Hanus H., 1997. Effect of slurry application and mineral nitrogen fertilization on $\mathrm{N}$ leaching in different crop combinations. J. Agric. Sci. 128:79-86. 